\title{
Tingkat Pelaksanaan Problem-Based Learning di Fakultas Kedokteran Universitas Gadjah Mada Berdasarkan Pembelajaran Konstruktif, Mandiri, Kolaboratif, dan Kontekstual
}

\author{
Banu Aji Dibyasakti, Gandes Retno Rahayu, Yoyo Suhoyo \\ Fakultas Kedokteran Universitas Gadjah Mada \\ Yogyakarta
}

\begin{abstract}
Background: Problem-based Learning (PBL) is a new strategy on a learning system. There are four basic theories regarding $P B L$ such as constructive, self-directed, collaborative, and contextual learning. The success of the implemention of PBL in one institution can be measured by the implementation of its four basic theories. Faculty of Medicine UGM (FM UGM) has been implementing PBL as their curriculum since 2002, however there have not been any conducted research that measure the implementation of PBL in FM UGM towards its 4 (four) basic theories.

Objectives: (1) To validate instrumen developed by Romauli et al ${ }^{8}$ that can measure the implementation level of PBL towards its 4 basic theories.(2) To measure the implementation level of PBL in FM UGM towards its 4 basic theories. (3) To compare the implementation level of PBL based on students' academic level and regular/international program. Method: This research used quantitative non-experimental research with cross-sectional design. 321 students from $2^{\text {nd }}$ (2008) and $3^{\text {rd }}$ (2007) students'batch regular and international program filled the questionnaire developed by Romauli et al (2009) which had been reliable (Alpha Cronbach) and validated (Pearson Moment Product) twice previously. The data were analyzed using mean analysis to measure the implementation level of PBL towards its four basic theories. This research also compared the implementation level of PBL based on students' academic level and regular/international by using Independent Sample t-test.

Results and Discussion: (1) Instrument developed by Romauli et al (8) had high validity and reliability level (á=0,01 and $r=0$,931). (2) The implementation level of PBL in FM UGM towards constructive, self-directed, collaborative, and contextual learning were in moderate level (1,72 $\pm 0,28 ; \min O \&$ max 3). (3) There were not any significant differences of the implementation level of PBL among $2007 \varepsilon 2008$ batch $(p>0,05)$. There were any significant differences of the implementation level of PBL among regular $\mathcal{E}$ international students regarding constructive $\mathcal{E}$ contextual learning $(p<0,05)$, however there were not any significant differences for self-directed $\mathcal{E}$ collaborative learning, $(p>0,05)$.

Conclusion: Instrument developed by Romauli et al (2009) had high validity and reliability. The implementation level of PBL were in moderate level. There were not any significant differences of the implementation level of PBL among two different students' batch. There were any significant differences of the implementation level of PBL among regular E international students.
\end{abstract}

Keywords: PBL, constructive, self-directed, collaborative, contextual learning, FM UGM

\begin{abstract}
Abstrak
Latar Belakang: Problem-based Learning (PBL) merupakan suatu strategi baru dalam sistem pendidikan. PBL didasarkan pada empat teori dasar yaitu pembelajaran konstruktif, mandiri, kolaboratif, dan kontekstual. Keberhasilan pelaksanaan PBL pada suatu institusi dapat diukur melalui pelaksanaan keempat teori dasarnya. FK UGM telah menerapkan PBL sejak tahun 2002, namun belum ada penelitian yang mengukur tingkat pelaksanaan PBL berdasarkan keempat teorinya di FK UGM.
\end{abstract}

Korespondensi: Telp:0274-562139; Email: gandes_rr@hotmail.com 
Tujuan: (1) Memvalidasi instrumen Romauli $\mathrm{dkk}^{8}$ yang dapat mengukur tingkat pelaksanaan PBL berdasarkan ke-empat teori dasarnya. (2) Mengetahui tingkat pelaksanaan PBL di FK UGM berdasarkan keempat teori dasarnya. (3) Membandingkan tingkat pelaksanaan PBL di FK UGM berdasarkan karakteristik angkatan, dan program reguler/internasional.

Metode: Penelitian ini merupakan penelitian kuantitatif non-eksperimental dengan rancangan cross-sectional. Dalam penelitian ini, 321 mahasiswa Pendidikan Dokter FK UGM tahun kedua (2008) dan keempat (2007) program Reguler dan Internasional mengisi kuesioner yang dikembangkan Romauli dkk8 yang telah diuji validitas (Pearson Product Moment) dan reliabilitas (Alpha Cronbach) sebelumnya sebanyak dua kali. Kemudian dilakukan analisis rata-rata untuk memperoleh tingkat pelaksanaan PBL berdasarkan ke-empat teorinya. Penelitian ini juga membandingkan hasil yang didapat antara mahasiswa tahun kedua (2008) dan ke-3 (2007), serta program reguler dan internasional dengan menggunakan metode independent sample t-test.

Hasil dan Pembahasan: (1) Kuesioner dalam penelitian ini memiliki validitas dan reliabilitas yang tinggi ( $a ́=0,01$ dan $r=0,931$ ). (2) Tingkat pelaksanaan PBL di FK UGM berdasarkan pembelajaran konstruktif, mandiri, kolaboratif, dan kontekstual berada pada tingkat sedang $(1,72 \pm 0,28$; minimal 0 dan maksimal 3). (3) Tidak terdapat perbedaan yang bermakna pelaksanaan PBL antara angkatan 2007 dan 2008 ( $p>0,05)$. Terdapat perbedaan yang bermakna antara pelaksanaan PBL di program reguler dan internasional dalam pembelajaran konstruktif dan kontekstual $(p<0,05)$, namun tidak terdapat perbedaan yang bermakna untuk pembelajaran mandiri dan kolaboratif $(p>0,05)$.

Kesimpulan: Kuesioner yang dikembangkan oleh Romauli $\mathrm{dkk}^{8}$ merupakan kuesioner yang valid dan reliable untuk mengukur tingkat pelaksanaan PBL berdasarkan keempat teorinya. Tingkat pelaksanaan PBL di FK UGM berdasarkan keempat teorinya berada pada tingkat sedang. Tidak ada perbedaan yang bermakna antara dua angkatan yang berbeda, tetapi terdapat perbedaan yang bermakna antara program reguler/internasional.

Kata Kunci: PBL, pembelajaran konstruktif, mandiri, kolaboratif, kontekstual, FK UGM

\section{LATAR BELAKANG}

Problem-based Learning (PBL) merupakan suatu strategi baru dalam sistem pendidikan. Problem-Based Learning saat ini sudah sangat luas digunakan di dunia, khususnya di Fakultas Kedokteran. PBL sendiri diperkenalkan oleh Howard Barrows sejak tahun 1969 di Fakultas Kedokteran McMaster, Kanada.

PBL didasarkan oleh empat teori dasar ${ }^{1}$, yaitu pembelajaran konstruktif, mandiri, kolaboratif, dan kontekstual. Pembelajaran konstruktif merupakan suatu teori belajar yang menjelaskan bahwa mahasiswa harus membangun pengetahuannya sendiri. ${ }^{1,2}$ Pembelajaran mandiri menjelaskan bahwa proses belajar terjadi atas keinginan mahasiswa itu sendiri. ${ }^{1,2,3,4,5,6}$ Pembelajaran kolaboratif menjelaskan bahwa suatu proses pembelajaran harus mampu memfasilitasi terjadinya interaksi antar mahasiswa agar terjadi proses pertukaran informasi. ${ }^{1,7}$ Pembelajaran kontekstual menjelaskan bahwa suatu proses pembelajaran harus mampu menggambarkan situasi dan kondisi lingkungan, tempat pengetahuan tersebut digunakan. , $, 2,3^{2}$

Suatu institusi pendidikan yang menerapkan PBL, harus dapat mengukur tingkat keberhasilan dari pelaksanaan PBL di institusi tersebut dilihat dari tidak jadi teori dasarnya. Dolman et $\mathrm{al}^{1}$ yang melakukan analisis terhadap penelitian-penelitian terkait PBL juga menyampaikan bahwa diperlukan penelitian mengenai PBL ditinjau dari ke-empat teori dasarnya. Sehingga merupakan hal yang penting untuk mengetahui cara mengukur tingkat pelaksanaan ke-empat teori tersebut.

Fakultas Kedokteran Universitas Gadjah Mada (FK UGM) telah menerapkan PBL sejak tahun 1992 dengan sistem hybrid PBL yang bersifat sederhana dengan penerapan modul dalam tiap semester dan belum terdiri dari sistem blok. Tahun 2002, FK UGM mulai menggunakan $\mathrm{PBL}$ curriculum yang telah mengubah seluruh kurikulum konvensional menjadi sistem blok. ${ }^{4}$ Selain itu, di tahun yang sama, FK UGM juga membuka 
Program Internasional yang memberikan kesempatan bagi mahasiswa asing untuk belajar di FK UGM. Sehingga berdasarkan hal tersebut diperlukan suatu penelitian sebagai bahan evaluasi tentang pelaksanaan PBL di FK UGM berdasarkan ke-empat teori dasarnya, dilihat dari karakteristik angkatan dan program reguler/ internasional.

\section{TUJUAN}

Tujuan penelitian adalah untuk (1) memvalidasi instrumen untuk mengukur tingkat pelaksanaan keempat teori dasar PBL, (2) mengetahui tingkat pelaksanaan PBL di FK UGM berdasarkan proses pembelajaran konstruktif, mandiri, kolaboratif, dan kontekstual, dan (3) membandingkan tingkat pelaksanaan PBL di FK UGM berdasarkan karakteristik angkatan, dan program reguler/internasional.

\section{METODE}

Penelitian ini merupakan penelitian kuantitatif noneksperimental dengan rancangan cross-sectional. Penelitian ini menggunakan kuesioner yang dikembangkan dari hasil penelitian Romauli et al ${ }^{8}$ dengan judul "IndikatorIndikator Belajar Secara Konstruktif, Mandiri, Kolaboratif, dan Kontekstual" dengan hasil berupa indikator tingkat pelaksanaan pembelajaran konstruktif, mandiri, kolaboratif, dan kontekstual pada pelaksanaan PBL.

Penilaian tingkat pelaksanaan pembelajaran konstruktif, mandiri, kolaboratif, dan kontekstual dilakukan dengan mencari rata-rata nilai jawaban kuesioner. Nilai jawaban kuesioner diambil dengan menjumlahkan skor masingmasing jawaban dari setiap item pertanyaan yang ada. Seluruh item pertanyaan terbagi menjadi 4 sub skala. Subskala A terdiri dari 14 item pertanyaan penilaian tingkat pelaksanaan pembelajaran konstruktif. Subskala B terdiri dari 25 item pertanyaan penilaian tingkat pelaksanaan pembelajaran mandiri. Sub skala $\mathrm{C}$ terdiri dari 12 item pertanyaan penilaian tingkat pelaksanaan pembelajaran kolaboratif. Sub skala D terdiri dari 12 item pertanyaan penilaian tingkat pelaksanaan pembelajaran kontekstual. Setiap pertanyaan memiliki 4 buah pilihan jawaban dengan menggunakan skala Likert, dengan kriteria 0: tidak pernah, 1: jarang, 2: sering, dan 3: selalu.
Penelitian ini terdiri dari 4 tahap. Tahap pertama adalah uji validitas dan reliabilitas instrumen. Tahap ini merupakan tahap pertama dalam pengujian validitas dan reliabilitas item-item dalam kuesioner. Validitas yang diuji adalah validitas konstruksi. Instrumen dikatakan memiliki validitas konstruksi, jika instrumen tersebut dapat mengukur gejala sesuai dengan yang didefinisikan. ${ }^{9}$ Untuk mengukur validitas konstruksi instrumen dalam penelitian ini, dilakukan dengan menggunakan uji validitas item yaitu uji korelasi Pearson Moment Product. Pengujian ini ditujukan untuk mengetahui bahwa item (pertanyaan) mempunyai dukungan yang kuat terhadap skor total. Suatu item pertanyaan dapat disebut memiliki validitas yang tinggi jika memiliki korelasi yang tinggi dengan skor total item. ${ }^{9} 10$ Pengujian validitas item ini menggunakan komputer dengan menggunakan perangkat lunak statistika.

Pengujian reliabilitas instrumen dalam penelitian ini dilakukan secara internal dengan menguji konsistensi item pertanyaan (internal consistency). Pengujian ini menggunakan uji Alpha-Cronbach. Suatu item pertanyaan disebut memiliki reliabilitas yang tinggi jika memiliki nilai $r>0.7 .^{10}$

Hasil dari uji validitas dan reliabilitas pertama ini akan digunakan untuk memperbaiki item-item dalam kuesioner. Selanjutnya, hasil tersebut akan dilakukan uji validitas dan reliabilitas yang kedua terhadap seluruh subjek penelitian.

Tahap kedua adalah tahap penyebaran kuesioner. Tahap ini bertujuan untuk melakukan pengambilan data penelitian. Subjek dari penelitian ini yaitu angkatan 2007 dan 2008 Pendidikan Dokter FK UGM Program Reguler dan Internasional. Pada tahap ini, peneliti menyebarkan kuesioner kepada seluruh subjek penelitian pada saat kuliah. Peneliti memberikan kuesioner kepada seluruh responden sebelum kuliah dimulai, kemudian kuesioner yang telah diisi dikembalikan setelah kuliah berakhir.

Tahap ketiga adalah analisis data. Tahap ini bertujuan untuk menganalisis data penelitian untuk mencapai tujuan penelitian. Tahap ini terdiri dari beberapa proses, yaitu untuk mengetahui penilaian tingkat pelaksanaan PBL di FKUGM berdasarkan pem-belajaran konstruktif, mandiri, kolaboratif, dan kontekstual, dilakukan dengan menghitung rata-rata nilai jawaban kuesioner. Nilai jawaban yang dihitung rata-ratanya tersebut terdiri dari 
dua jenis nilai, yaitu nilai total kuesioner dan nilai per subskala kuesioner.

Pada penilaian rata-rata nilai total kuesioner, dihitung rata-rata nilai total tingkat pelaksanaan PBL di FK UGM. Nilai total tingkat pelaksanaan PBL di FK UGM tersebut diperoleh dari hasil penjumlahan nilai seluruh subskala dalam kuesioner. Hasilnya kemudian dikelompokkan menjadi tiga kategori, yaitu (a) rendah (0-1), (b) sedang $(>1-2)$, (c) tinggi $(>2)$.

Pada penilaian rata-rata nilai per sub skala kuesioner, dihitung rata-rata nilai dari masing-masing subskala kuesioner. Hasilnya, kemudian dikelompokkan menjadi beberapa kategori menurut subskala masing-masing.

Tingkat pelaksanaan pembelajaran konstruktif dikelompokkan menjadi tiga kategori, yaitu (0-1) rendah: mahasiswa belum membangun ilmu pengetahuannya, (>1-2) sedang: mahasiswa telah membangun ilmu pengetahuannya, namun belum maksimal, dan $(>2)$ tinggi: mahasiswa telah membangun ilmu pengetahuannya dengan baik.

Tingkat pelaksanaan pembelajaran mandiri dikelompokkan menjadi tiga kategori, yaitu $(0-1)$ rendah: kontrol proses belajar belum berada pada diri mahasiswa sendiri, (>1-2) sedang: kontrol proses belajar telah berada pada diri mahasiswa sendiri, namun belum maksimal, dan (>2) tinggi: kontrol proses belajar telah berada pada diri mahasiswa sendiri.

Tingkat pelaksanaan pembelajaran kolaboratif dikelompokkan menjadi tiga kategori, yaitu $(0-1)$ rendah: belum terjadinya interaksi antar mahasiswa dalam proses pembelajaran, $(>1-2)$ sedang: interaksi antar mahasiswa telah terjalin, namun belum maksimal, dan $(>2)$ tinggi:terjadi interaksi mahasiswa yang menghasilkan efek yang positif dalam proses pembelajaran.
Tingkat pelaksanaan pembelajaran kontekstual dikelompokkan menjadi tiga kategori, yaitu (0-1) rendah: proses pembelajaran tidak mencerminkan situasi dan kondisi lingkungan, tempat pengetahuan tersebut akan digunakan, $(>1-2)$ sedang: proses pembelajaran telah mencerminkan situasi dan kondisi lingkungan, tempat pengetahuan tersebut akan digunakan, namun belum maksimal, dan (>2) tinggi: proses pembelajaran telah mencerminkan situasi dan kondisi lingkungan, tempat pengetahuan tersebut akan digunakan.

Untuk mengetahui: (a) perbedaan bermakna rata-rata nilai jawaban kuesioner antara mahasiswa angkatan 2007 dan mahasiswa angkatan 2008 dan (b) perbedaan bermakna rata-rata nilai jawaban kuesioner antara mahasiswa program reguler dan mahasiswa program internasional, menggunakan Uji Independent Sample TTest.

\section{HASIL DAN PEMBAHASAN}

Pada penelitian ini, seluruh responden berjumlah 321 mahasiswa yang berasal dari angkatan Tahun 2007 dan 2008 Pendidikan Dokter FK UGM Program Reguler dan Internasional. Tabel 1 menunjukkan distribusi subjek penelitian dan tingkat respon responden.

Seluruh item dalam kuesioner pada penelitian ini dilakukan uji validitas dan reliabilitas sebanyak dua kali. Uji validitas dan reliabilitas pertama dilakukan dengan sampel sebanyak 30 mahasiswa yang berasal dari mahasiswa Pendidikan Dokter FK UGM angkatan 2006, 2007, dan 2008. Uji validitas instrumen ini menggunakan uji Pearson Moment Product. Tabel 2 menunjukkan hasil uji validitas instrumen penelitian kepada 30 mahasiswa, yaitu:

Tabel 1. Distribusi dan tingkat respon responden

\begin{tabular}{ccccc} 
& \multicolumn{2}{c}{2007} & \multicolumn{2}{c}{2008} \\
\cline { 2 - 5 } & Reguler & Internasional & Reguler & Internasional \\
Tingkat respon & $70 / 191-$ & $51 / 77-$ & $126 / 185-$ & $74 / 85-$ \\
responden & $36,6 \%$ & $66,2 \%$ & $68,1 \%$ & $87,1 \%$ \\
\hline
\end{tabular}


Tabel 2. Hasil uji validitas instrumen penelitian kepada 30 mahasiswa

\begin{tabular}{|c|c|c|c|c|}
\hline Sub skala & $\begin{array}{c}\text { Jumlah item dengan } \\
\text { taraf kebermaknaan } \\
0.01\end{array}$ & $\begin{array}{c}\text { Jumlah item dengan } \\
\text { taraf kebermaknaan } \\
0.05\end{array}$ & $\begin{array}{c}\text { Tidak } \\
\text { bermakna }\end{array}$ & Total Item \\
\hline $\begin{array}{l}\text { Pembelajaran } \\
\text { konstruktif }\end{array}$ & 9 & 4 & 3 & 16 \\
\hline Pembelajaran mandiri & 18 & 5 & 5 & 28 \\
\hline $\begin{array}{l}\text { Pembelajaran } \\
\text { kolaboratif }\end{array}$ & 10 & 1 & 5 & 16 \\
\hline $\begin{array}{l}\text { Pembelajaran } \\
\text { kontekstual }\end{array}$ & 10 & 1 & 1 & 12 \\
\hline \multicolumn{4}{|c|}{ Total } & 72 \\
\hline
\end{tabular}

Suatu item pertanyaan dapat disebut memiliki validitas yang tinggi jika memiliki korelasi yang tinggi dengan skor total item. ${ }^{9,10}$ Korelasi tersebut ditunjukkan oleh taraf kebermaknaan item tersebut terhadap skor totalnya. Taraf kebermaknaan adalah kemungkinan terjadinya kesalahan penolakan hipotesis nol yang benar dalam penelitian. Makin kecil taraf kebermaknaan dari suatu item, berarti semakin tinggi tingkat kepercayaan item tersebut. ${ }^{11}$

Uji reliabilitas instrumen ini menggunakan uji AlphaCronbach. Tabel 3 menunjukkan hasil uji reliabilitas instrumen penelitian kepada 30 mahasiswa, yaitu:

Tabel 3. Hasil uji reliabilitas instrumen penelitian kepada 30 mahasiswa

\begin{tabular}{lc}
\multicolumn{1}{c}{ Jenis Pembelajaran } & Cronbach's Alpha \\
\hline Pembelajaran konstruktif & 0,80 \\
\hline Pembelajaran mandiri & 0,85 \\
\hline Pembelajaran kolaboratif & 0,78 \\
\hline Pembelajaran kontekstual & 0,88 \\
\hline Total (PBL) & 0,93 \\
\hline
\end{tabular}

Suatu item disebut memiliki reliabilitas yang tinggi jika memiliki $r>0,7$. Berdasarkan hasil di atas, maka seluruh item dalam instrumen ini memiliki reliabilitas yang tinggi $(r>0,7)$.
Berdasarkan uji validitas dan reliabilitas kepada 30 mahasiswa, diadakan beberapa perubahan item pertanyaan dalam kuesioner yang bertujuan untuk memperbaiki item pertanyaan dalam kuesioner penelitian. Perubahan tersebut diantaranya: (a) pada item pertanyaan pembelajaran konstruktif, terdapat 2 item yang dihapus dan 1 item yang diperbaiki, (b) pada item pertanyaan pembelajaran mandiri, terdapat 3 item yang dihapus dan 2 item yang diperbaiki, (c) pada item pertanyaan pembelajaran kolaboratif, terdapat 4 item yang dihapus dan 1 item yang diperbaiki, (d) pada item pertanyaan pembelajaran kontekstual, hanya terdapat 1 item yang diperbaiki.

Uji validitas dan reliabilitas yang kedua dilakukan kepada seluruh responden penelitian yang berjumlah 321 mahasiswa yang berasal dari mahasiswa Pendidikan Dokter FK UGM angkatan tahun 2007 dan 2008. Uji validitas instrumen ini menggunakan uji Pearson Moment Product. Tabel 4 menunjukkan hasil uji validitas instrumen penelitian kepada 321 mahasiswa. 
Tabel 4. Hasil uji validitas instrumen kepada 321 mahasiswa

\begin{tabular}{ccccc} 
Sub skala & $\begin{array}{c}\text { Jumlah item dengan } \\
\text { taraf kebermaknaan } \\
\mathbf{0 . 0 1}\end{array}$ & $\begin{array}{c}\text { Jumlah item dengan } \\
\text { taraf kebermaknaan } \\
\mathbf{0 . 0 5}\end{array}$ & $\begin{array}{c}\text { Tidak } \\
\text { bermakna }\end{array}$ & Total Item \\
$\begin{array}{c}\text { Pembelajaran } \\
\text { konstruktif }\end{array}$ & 14 & 0 & 0 & 14 \\
\hline $\begin{array}{c}\text { Permbelajaran mandiri } \\
\text { Pembclajaran } \\
\text { kolaboratif }\end{array}$ & 25 & 0 & 0 & 25 \\
\hline $\begin{array}{c}\text { Pembelajaran } \\
\text { kontekstual }\end{array}$ & 12 & 0 & 0 & 12 \\
\hline & 12 & 0 & 0 & $\mathbf{6 3}$ \\
\hline
\end{tabular}

Berdasarkan hasil uji validitas yang kedua, diperoleh hasil semua item memiliki korelasi yang tinggi terhadap skor totalnya. Hal ini ditunjukkan dengan seluruh item pertanyaan memiliki taraf kebermaknaan sebesar 0,01.

Uji reliabilitas instrumen ini menggunakan uji AlphaCronbach. Tabel 5 menunjukkan hasil uji reliabilitas instrumen penelitian kepada 321 mahasiswa, yaitu:

Tabel 5. Hasil uji reliabilitas item kuesioner kepada 321 mahasiswa

\begin{tabular}{lc}
\multicolumn{1}{c}{ Jenis Pembelajaran } & Cronbach's Alpha \\
\hline Pembelajaran konstruktif & 0,80 \\
\hline Pembelajaran mandiri & 0,85 \\
\hline Pembelajaran kolaboratif & 0,78 \\
\hline Pembelajaran kontekstual & 0,88 \\
\hline \multicolumn{1}{c}{ Total (PBL) } & $\mathbf{0 , 9 3}$ \\
\hline
\end{tabular}

Suatu item disebut memiliki reliabilitas yang tinggi jika memiliki $r>0,7$. Berdasarkan hasil di atas, maka seluruh item dalam instrumen ini memiliki reliabilitas yang tinggi $(r>0,7)$.
Penilaian tingkat pelaksanaan pembelajaran konstruktif, mandiri, kolaboratif, dan kontekstual diukur dengan menggunakan kuesioner kepada 321 mahasiswa. Tabel 6 menunjukkan rata-rata nilai total kuesioner dan ratarata nilai per sub skala kuesioner.

Berdasarkan Tabel 6, penilaian tingkat pelaksanaan pembelajaran konstruktif di FK UGM adalah sedang: mahasiswa telah membangun ilmu pengetahuannya, namun belum maksimal $(1,77 \pm 0,33)$. Penilaian tingkat pelaksanaan pembelajaran mandiri di FK UGM adalah sedang: kontrol proses belajar telah berada pada diri mahasiswa sendiri, namun belum maksimal $(1,68 \pm 0,30)$. Penilaian tingkat pelaksanaan pembelajaran kolaboratif di FK UGM adalah sedang: interaksi antar mahasiswa telah terjalin, namun belum maksimal $(1,85 \pm 0,34)$. Penilaian tingkat pelaksanaan pembelajaran kontekstual di FK UGM adalah sedang: proses pembelajaran telah mencerminkan situasi dan kondisi lingkungan, tempat pengetahuan tersebut akan digunakan, namun belum maksimal $(1,61 \pm 0,42)$. Sehingga berdasarkan ke-empat penilaian di atas, diperoleh penilaian pelaksanaan PBL di FK UGM adalah sedang $(1,72 \pm 0,28)$.

Tabel 6. Rata-rata nilai per subskala kuesioner dan rata-rata nilai total kuesioner

\begin{tabular}{|c|c|c|c|c|c|}
\hline Sub skala & $\begin{array}{l}\text { Jumlah } \\
\text { Item }\end{array}$ & $\begin{array}{c}\text { Nilai } \\
\text { Minimal }\end{array}$ & $\begin{array}{c}\text { Nilai } \\
\text { Maksimal }\end{array}$ & $\begin{array}{l}\text { Rata-Rata Nilai } \\
\text { Item Kuesioner }\end{array}$ & Tingkat \\
\hline $\begin{array}{l}\text { Pembelajaran } \\
\text { konstruktif }\end{array}$ & 14 & 0 & 3 & $1,77 \pm 0,33$ & Sedang \\
\hline Pembelajaran mandiri & 25 & 0 & 3 & $1,68 \pm 0,30$ & Sedang \\
\hline Pembelajaran kolaboratif & 12 & 0 & 3 & $1,85 \pm 0,34$ & Sedang \\
\hline $\begin{array}{l}\text { Pembelajaran } \\
\text { kontekstual }\end{array}$ & 12 & 0 & 3 & $1,61 \pm 0,42$ & Sedang \\
\hline $\begin{array}{l}\text { Tingkat Pelaksanaan } \\
\text { PBL }\end{array}$ & 63 & 0 & 3 & $1,72 \pm 0,28$ & Sedang \\
\hline
\end{tabular}


Perbandingan tingkat penilaian pelaksanaan pembelajaran konstruktif, mandiri, kolaboratif, dan kontekstual berdasarkan karakteristik mahasiswa menggunakan uji independent sample t-test. Karakteristik mahasiswa yang dibandingkan adalah angkatan dan program reguler/internasional.
Tabel 7 menunjukkan perbandingan penilaian tingkat pelaksanaan PBL berdasarkan pembelajaran konstruktif, mandiri, kolaboratif, dan kontekstual berdasarkan karakteristik angkatan mahasiswa.

Tabel 7. Perbandingan penilaian tingkat pelaksanaan PBL berdasarkan pembelajaran konstruktif, mandiri, kolaboratif, dan kontekstual berdasarkan karakteristik angkatan mahasiswa

\begin{tabular}{lccc}
\multicolumn{1}{c}{ Sub skala } & Rata-rata 2007 & Rata-rata 2008 & Kebermaknaan (p) \\
Pembelajaran konstruktif & $1,77 \pm 0,32$ & $1,77 \pm 0,35$ & 0,92 \\
\hline Pembelajaran mandiri & $1,68 \pm 0,29$ & $1,68 \pm 0,31$ & 0,99 \\
\hline Pembelajaran kolaboratif & $1,85 \pm 0,31$ & $1,85 \pm 0,36$ & 0,86 \\
\hline Pembelajaran kontekstual & $1,62 \pm 0,42$ & $1,60 \pm 0,43$ & 0,70 \\
\hline $\begin{array}{l}\text { Total Penilaian Tingkat } \\
\text { Pelaksanaan PBL }\end{array}$ & $1,72 \pm 0,26$ & $1,72 \pm 0,29$ & 0,94 \\
\hline
\end{tabular}

Dengan menggunakan metode independent sample t-test, diperoleh hasil: (a) tidak ada perbedaan bermakna tingkat pelaksanaan pembelajaran konstruktif antara angkatan 2007 dan angkatan 2008 ( p > 0.05), (b) tidak ada perbedaan bermakna tingkat pelaksanaan pembelajaran mandiri antara angkatan 2007 dan angkatan 2008 (p > 0.05), (c) tidak ada perbedaan bermakna tingkat pelaksanaan pembelajaran kolaboratif antara angkatan 2007 dan angkatan 2008 (p > 0.05), (d) tidak ada perbedaan bermakna tingkat pelaksanaan pembelajaran konstruktif angkatan 2007 dan angkatan 2008 ( $p$ > 0.05), (e) tidak ada perbedaan bermakna tingkat pelaksanaan PBL secara keseluruhan antara angkatan 2007 dan angkatan 2008 ( $>$ > 0.05).

Tabel 8 Perbandingan penilaian tingkat pelaksanaan PBL berdasarkan pembelajaran konstruktif, mandiri, kolaboratif, dan kontekstual berdasarkan karakteristik program reguler/internasional.

\begin{tabular}{lcll}
\multicolumn{1}{c}{ Sub skala } & $\begin{array}{c}\text { Ratarata } \\
\text { Program Reguler }\end{array}$ & $\begin{array}{c}\text { Ratarata } \\
\text { Program } \\
\text { internasional }\end{array}$ & Kebermaknaan (p) \\
\hline Pembelajaran konstruktif & $1,72 \pm 0,30$ & $1,85 \pm 0,38$ & 0,001 \\
\hline Pembelajaran mandiri & $1,66 \pm 0,26$ & $1,71 \pm 0,36$ & 0,119 \\
\hline Pembelajaran kolaboratif & $1,86 \pm 0,33$ & $1,84 \pm 0,37$ & 0,576 \\
\hline Pembelajaran knntekstual & $1,52 \pm 0,37$ & $1,74 \pm 0,47$ & 0,000 \\
\hline $\begin{array}{l}\text { Total Penilaian Tingkat } \\
\text { Pelaksauldau PBL }\end{array}$ & $1,68 \pm 0,23$ & $1,78 \pm 0,33$ & 0,006 \\
\hline
\end{tabular}

Dengan menggunakan metode independent sample t-test, diperoleh hasil: (a) terdapat perbedaan bermakna tingkat pelaksanaan pembelajaran konstruktif antara mahasiswa program reguler dan internasional $(\mathrm{p}<0.05)$, (b) tidak ada perbedaan bermakna tingkat pelaksanaan pembelajaran mandiri antara mahasiswa program reguler dan internasional ( $p>0.05$ ), (c) tidak ada perbedaan bermakna pelaksanaan pembelajaran kolaboratif antara mahasiswa program reguler dan internasional $(\mathrm{p}>0.05)$, (d) terdapat perbedaan bermakna tingkat pelaksanaan pembelajaran kontekstual mahasiswa program reguler dan internasional $(\mathrm{p}<0.05)$, (e) terdapat perbedaan bermakna tingkat pelaksanaan PBL secara keseluruhan antara mahasiswa program reguler dan internasional $(p<0.05)$. 
Berdasarkan Tabel 2, diperoleh hasil terdapat 9 item pertanyaan pembelajaran konstruktif yang memiliki validitas dengan taraf kebermaknaan 0,01 dan 4 item pertanyaan yang memiliki validitas dengan taraf kebermaknaan 0,05. Taraf kebermaknaan menunjukkan kemungkinan terjadinya kesalahan menolak hipotesis nol yang ternyata benar. Taraf kebermaknaan 0,01 berarti bahwa kemungkinan terjadinya kesalahan tersebut dalam penelitian adalah $1 \%$, sedangkan taraf kebermaknaan 0,05 berarti bahwa kemungkinan terjadinya kesalahan tersebut dalam penelitian adalah sebesar 5\%.

Taraf kebermaknaan yang rendah menunjukkan tingkat kepercayaan yang tinggi atau dalam hal ini memiliki korelasi yang tinggi dengan skor totalnya. Taraf kebermaknaan yang termasuk rendah adalah sebesar 0,01 dan 0,05. ${ }^{9,11}$ Sehingga dapat dikatakan bahwa 13 item pertanyaan tersebut telah memiliki korelasi yang tinggi terhadap skor total item sehingga dapat dengan tepat mengukur pelaksanaan pembelajaran konstruktif dalam PBL. ${ }^{9,10,11}$

Selain itu, diperoleh juga 3 item pertanyaan yang memiliki korelasi yang rendah terhadap skor total item pertanyaan, yaitu (a) Nomor 5: Saya menghubungkan materi kuliah dan materi praktikum dengan diskusi di tutorial, (b) Nomor 12: Saya membuat mind mapping di akhir pertemuan tutorial pertama, dan (c) Nomor 14: Saya dapat membuat alur materi dari suatu penyakit di akhir tutorial. Peneliti akhirnya melakukan perubahan terhadap item-item tersebut dengan menghapus item nomor 12 dan 14, dan merubah redaksional item nomor 5 menjadi: Saya menghubungkan materi kuliah dan materi praktikum dalam tutorial.

Pada uji validitas kedua kepada 321 mahasiswa, ternyata diperoleh seluruh item pertanyaan pembelajaran konstruktif berkorelasi dengan skor totalnya pada taraf kebermaknaan 0,01 . Hal ini menunjukkan bahwa seluruh item pembelajaran konstruktif telah memiliki korelasi yang tinggi terhadap skor total itemnya sehingga dapat dengan tepat mengukur pelaksanaan pembelajaran konstruktif dalam PBL. 9,10,11

Berdasarkan Tabel 2, diperoleh hasil terdapat 18 item pertanyaan pembelajaran mandiri yang memiliki validitas dengan taraf kebermaknaan 0,01 dan 5 item pertanyaan yang memiliki validitas dengan taraf kebermaknaan 0,05. Hal ini menunjukkan bahwa 23 item pertanyaan tersebut telah memiliki korelasi yang tinggi terhadap skor total item. ${ }^{9,10,11}$ Selain itu, diperoleh juga 5 item pertanyaan yang memiliki korelasi yang rendah dengan skor total item pertanyaan, yaitu (a) Nomor 8: Saya menyadari pentingnya belajar, (b) Nomor 19: Saya membaca bahan praktikum sebelum praktikum, (c) Nomor 21: Saya memotivasi diri sendiri dalam belajar, (d) Nomor 23: Saya menciptakan suasana belajar yang nyaman bagi saya, dan (e) Nomor 25: Saya mengetahui kekurangan saya dalam belajar. Peneliti akhirnya melakukan perubahan terhadap item-item tersebut dengan menghapus item Nomor 19, 23 dan 25, dan merubah redaksional item nomor 8 dan 21 menjadi (a) Nomor 8: Saya menyadari kepentingan mengapa saya mempelajari topik tertentu, (b) Nomor 21: Saya mempunyai motivasi dari diri saya sendiri untuk belajar.

Pada uji validitas kedua kepada 321 mahasiswa, didapatkan bahwa seluruh item pertanyaan pembelajaran mandiri berkorelasi dengan skor totalnya pada taraf kebermaknaan 0,01 . Hal ini menunjukkan bahwa seluruh item pembelajaran mandiri telah memiliki korelasi yang tinggi terhadap skor total itemnya sehingga dapat dengan tepat mengukur pelaksanaan pembelajaran mandiri dalam PBL. ${ }^{9} 10,11$

Berdasarkan Tabel 2 , diperoleh hasil terdapat 10 item pertanyaan pembelajaran kolaboratif yang memiliki validitas dengan taraf kebermaknaan 0,01 dan 1 item pertanyaan yang memiliki validitas dengan taraf kebermaknaan 0,05. Hal ini menunjukkan bahwa 11 item pertanyaan tersebut telah memiliki korelasi yang tinggi terhadap skor total item sehingga dapat dengan tepat mengukur pelaksanaan pembelajaran kolaboratif dalam PBL. 9,10,11 Selain itu, diperoleh juga 5 item pertanyaan yang memiliki korelasi yang rendah dengan skor total item pertanyaan, yaitu (a) Nomor 4: Saya belajar bersama teman sebelum ujian blok, (b) Nomor 11: Saya melakukan diskusi materi kuliah setelah selesai kuliah, (c) nomor 12: Saya mendiskusikan soal pretest praktikum, (d) Nomor 13: Saya mendengarkan pendapat teman saat diskusi, dan (d) Nomor 14: Saya melakukan tanya jawab materi pembelajaran. Peneliti akhirnya melakukan perubahan terhadap item-item tersebut dengan menghapus item nomor 4, 11, 12, dan 14, dan merubah 
redaksional item nomor 13 menjadi: Saya menghargai pendapat teman saat diskusi.

Pada uji validitas kedua kepada 321 mahasiswa, ternyata diperoleh seluruh item pertanyaan pembelajaran kolaboratif telah berkorelasi dengan skor totalnya pada taraf kebermaknaan 0,01. Hal ini menunjukkan bahwa seluruh item pembelajaran mandiri telah memiliki korelasi yang tinggi terhadap skor total itemnya sehingga dapat dengan tepat mengukur pelaksanaan pembelajaran kolaboratif dalam PBL. 9,10,11

Berdasarkan Tabel 2, diperoleh hasil terdapat 10 item pertanyaan pembelajaran kontekstual yang memiliki validitas dengan taraf kebermaknaan 0,01 dan 1 item pertanyaan yang memiliki validitas dengan taraf kebermaknaan 0,05. Hal ini menunjukkan bahwa 11 item pertanyaan tersebut telah memiliki korelasi yang tinggi terhadap skor total item sehingga dapat dengan tepat mengukur pelaksanaan pembelajaran kontekstual dalam PBL. ${ }^{9,10,11}$ Selain itu, diperoleh juga 1 item pertanyaan yang memiliki korelasi yang rendah dengan skor total item pertanyaan, yaitu: Nomor 8. Saya membandingkan teori dalam ilmu yang saya pelajari dengan realitas dalam kehidupan. Peneliti akhirnya melakukan perubahan terhadap item tersebut dengan merubah redaksional item Nomor 8 menjadi: Saya membandingkan ilmu yang saya pelajari dengan kejadian-kejadian sehari-hari yang saya lihat atau alami.

Pada uji validitas kedua kepada 321 mahasiswa, ternyata diperoleh seluruh item pertanyaan pembelajaran kontekstual telah berkorelasi dengan skor totalnya pada taraf kebermaknaan 0,01. Hal ini menunjukkan bahwa seluruh item pembelajaran kontekstual telah memiliki korelasi yang tinggi terhadap skor total itemnya sehingga dapat dengan tepat mengukur pelaksanaan pembelajaran kontekstual dalam PBL. ${ }^{9,10,11}$

Berdasarkan hasil kedua uji validitas di atas, telah diperoleh item-item pertanyaan tingkat pelaksanaan pembelajaran konstruktif, mandiri, kolaboratif, dan kontekstual dalam kuesioner dengan validitas yang tinggi. Hal ini menunjukkan bahwa kuesioner dalam penelitian ini secara rasional telah mencerminkan tingkat pelaksanaan pembelajaran konstruktif, mandiri, kolaboratif, dan kontekstual.9,10
Berdasarkan Tabel 3, diperoleh hasil: (a) reliabilitas item pembelajaran konstruktif $=0,76$, (b) reliabilitas item pembelajaran mandiri $=0,88$, (c) reliabilitas item pembelajaran kolaboratif $=0,72$, (d) reliabilitas item pembelajaran kontekstual $=0,82$, dan (e) reliabilitas item $\mathrm{PBL}=0,92$. Nilai tersebut menunjukkan bahwa seluruh item pertanyaan dalam kuesioner penelitian telah memiliki reliabilitas yang tinggi $(r>0,7){ }^{10}$

Berdasarkan Tabel 5, diperoleh hasil: (a) reliabilitas item pembelajaran konstruktif $=0,80$, (b) reliabilitas item pembelajaran mandiri $=0,85$, (c) reliabilitas item pembelajaran kolaboratif $=0,78$, (d) reliabilitas item pembelajaran kontekstual $=0,88$, dan (e) reliabilitas item $P B L=0,93$. Nilai tersebut menunjukkan bahwa item pertanyaan dalam kuesioner penelitian telah memiliki reliabilitas yang tinggi $(r>0,7) .10$

Berdasarkan hasil kedua uji reliabilitas di atas, diperoleh seluruh item pertanyaan penilaian tingkat pelaksanaan PBL berdasarkan pembelajaran konstruktif, mandiri, kolaboratif, dan kontekstual telah memiliki reliabilitas yang tinggi. Hal ini menunjukkan bahwa kuesioner yang digunakan dalam penelitian ini telah dapat memberikan hasil yang konsisten dalam waktu yang berbeda. ${ }^{9}$

Tingkat pelaksanaan PBL di FK UGM berdasarkan hasil rata-rata penilaian tingkat pelaksanaan pembelajaran konstruktif, mandiri, kolaboratif, dan kontesktual adalah sedang (1,718). Tingkat pelaksanaan PBL yang sedang ini, menunjukkan bahwa (a) mahasiswa telah membangun ilmu pengetahuannya, namun belum maksimal, (b) kontrol proses belajar telah berada pada diri mahasiswa sendiri, namun belum maksimal, (c) interaksi antar mahasiswa telah terjalin, namun belum maksimal, dan (d) proses pembelajaran telah mencerminkan situasi dan kondisi lingkungan, tempat pengetahuan tersebut akan digunakan, namun belum maksimal.

Berdasarkan hasil rata-rata penilaian tingkat pelaksanaan pembelajaran konstruktif di FK UGM (Tabel 6), didapatkan pelaksanaan pembelajaran konstruktif di FK UGM adalah sedang: mahasiswa telah membangun ilmu pengetahuannya, namun belum maksimal $(1,77)$. Tingkat pelaksanaan pembelajaran konstruktif ditentukan oleh tiga hal, yaitu: (a) kualitas masalah yang diberikan kepada 
mahasiswa ${ }^{1,3,12}$, (b) aktivasi prior knowledge ${ }^{1}$, dan (c) proses elaborasi ilmu pengetahuan dalam diskusi tutorial ${ }^{1,2}$.

Hasil pelaksanaan pembelajaran konstruktif yang sedang dalam penelitian ini mungkin menunjukkan bahwa kualitas masalah yang dihadapi oleh mahasiswa masih belum benar-benar mampu untuk menstimulus mahasiswa dalam membangun ilmu pengetahuannya. Davis \& Harden ${ }^{3}$ menyebutkan bahwa masalah yang disampaikan kepada mahasiswa, dirancang untuk menjadi sebuah media dalam menyampaikan tujuantujuan belajar yang dibuat oleh fakultas. Tujuan belajar dari fakultas tersebut diwujudkan melalui berbagai macam aktivitas pembelajaran, di antaranya tutorial, kuliah, dan praktikum. ${ }^{13}$

Dalam kegiatan tutorial, masalah diwujudkan dalam bentuk skenario kasus. Skenario kasus semestinya dapat menciptakan suatu konflik pengetahuan di antara mahasiswa. Dengan adanya konflik pengetahuan, maka hal ini akan menstimulus mahasiswa untuk menggali informasi yang terkandung di dalamnya. ${ }^{14}$ Melalui skenario tersebut, mahasiswa dapat membangun suatu bangunan ilmu pengetahuan baru untuk memperkuat pengetahuan yang sudah ada sebelumnya. Selain itu, melalui skenario tersebut, seharusnya mahasiswa akan dapat mengetahui kebutuhan belajarnya yang sesuai dengan yang dibuat oleh fakultas. ${ }^{3}$ Terkait dengan skenario, tutor bertugas membantu mahasiswa untuk mengembangkan skenario kasus yang dihadapi oleh mahasiswa, tanpa memberikan ilmunya secara langsung. $1,5,6,15$

Dalam kegiatan kuliah, materi yang disampaikan oleh pengajar seharusnya dapat merepresentasikan permasalahan yang dihadapi oleh mahasiswa. Selain itu, dalam perkuliahan yang konstruktif, mahasiswa seharusnya dapat menanyakan hal-hal dari skenario masalah yang masih belum mendapatkan kejelasan. ${ }^{8}$ Melalui kejelasan dari pihak pengajar, diharapkan akan memudahkan mahasiswa untuk merangkai bangunan ilmu pengetahuannya.

Dalam kegiatan praktikum, materi praktikum juga semestinya berhubungan dengan permasalahan yang dihadapi mahasiswa. Selain itu dalam praktikum, mahasiswa juga diharapkan untuk menanyakan kepada pembimbing praktikum mengenai hal-hal yang belum mendapat kejelasan, khususnya hal yang berhubungan dengan materi praktikum tersebut. Melalui hal itu, mahasiswa diharapkan menjadi lebih mudah dalam merangkai bangunan ilmu pengetahuannya.

Hasil pembelajaran konstruktif yang sedang pada penelitian ini mungkin juga menunjukkan bahwa aktivasi dari prior knowledge mahasiswa masih berada pada tingkat sedang. Aktivasi prior knowledge berkaitan dengan proses pengaitan antara ilmu pengetahuan yang baru didapat dengan pengetahuan yang sudah. ${ }^{1}$ Dalam hal ini prior knowledge merupakan suatu pondasi dari ilmu pengetahuan yang dimiliki oleh mahasiswa. Prior knowledge yang kuat akan menjadi sebuah pondasi yang kuat. Aktivasi prior knowledge yang sedang pada penelitian ini menunjukkan bahwa pondasi ilmu pengetahuan mahasiswa belum sepenuhnya kuat. Charlin et $\mathrm{al}^{2}$ menyebutkan bahwa dengan adanya pondasi yang kuat, maka bangunan ilmu pengetahuan pada mahasiswa akan menjadi semakin kuat. Ketika suatu ilmu pengetahuan baru ditambahkan di antara prior knowledge yang kuat tersebut, maka pengetahuan baru tersebut akan dengan mudah untuk digunakan kembali.

Aktivasi prior knowledge dapat dilakukan dalam berbagai aktivitas pembelajaran. Romauli et $\mathrm{al}^{8}$ menyebutkan bahwa aktivasi prior knowledge pada diskusi tutorial dapat diwujudkan dengan mengingat kembali materi-materi yang sudah pernah dipelajarinya saat tutorial pertemuan pertama. Selain itu Dolman et al ${ }^{1}$ juga menyatakan bahwa dalam diskusi tutorial, tutor berfungsi untuk membantu memancing pengetahuan mahasiswa secara mendalam agar aktivasi prior knowledge dapat berlangsung dengan maksimal. Kemudian dalam kegiatan kuliah, aktivasi prior knowledge dapat diwujudkan dengan mengaitkan materi yang telah dipelajari sebelumnya dengan materi kuliah yang disampaikan oleh dosen pengajar.

Dalam kegiatan praktikum, aktivasi prior knowledge diperlukan untuk mengaitkan materi praktikum dengan materi yang telah dipelajari sebelumnya. Serta dalam kehidupan sehari-hari, mahasiswa semestinya dapat selalu mengingat-ingat kembali materi yang telah dipelajari sebelumnya dan menghubungkan materi tersebut dengan materi yang baru didapat. ${ }^{9}$ Dengan mengaktifkan prior knowledge mahasiswa, semestinya pondasi dari bangunan 
ilmu pengetahuan yang dimiliki mahasiswa akan menjadi lebih kuat. ${ }^{1}$

Selain terkait dengan masalah yang dihadapi mahasiswa serta proses aktivasi prior knowledge, hasil pembelajaran konstruktif yang sedang dalam penelitian ini juga dapat menunjukkan bahwa proses elaborasi ilmu pengeatahuan pada mahasiswa masih belum sepenuhnya terjadi. Savery $\&$ Duffy $^{14}$ dan Charlin et al ${ }^{2}$ menyebutkan bahwa proses elaborasi memungkinkan terjadinya interaksi antara mahasiswa dengan lingkungan di sekitarnya. Lingkungan tersebut dalam hal ini berperan dalam menguji kekuatan dan kebenaran dari pemahaman yang ada pada diri mahasiswa serta fungsinya dalam kehidupan. Selanjutnya, dari proses pengujian itulah kemudian akan dihasilkan suatu pengetahuan baru yang akan memperkuat bangunan ilmu pengetahuan mahasiswa.

Proses elaborasi ilmu pengetahuan dapat diwujudkan dalam berbagai macam aktivitas pembelajaran. Dolman et $\mathrm{al}^{1}$ mengatakan bahwa proses elaborasi ilmu pengetahuan dapat diwujudkan melalui aktivitas pertukaran informasi antar mahasiswa. Dalam diskusi tutorial, proses elaborasi ini dapat terwujud melalui aktivitas diskusi dari kasus yang dihadapi mahasiswa, kemudian juga mahasiswa seharusnya dapat menghubungkan teori dasar dengan teori klinis dari sebuah penyakit. ${ }^{8}$ Dalam kegiatan kuliah dan praktikum, elaborasi ilmu pengetahuan dapat terwujud dengan saling menghubungkan kedua materi tersebut satu sama lain, serta dapat juga dikaitkan dengan ilmu yang didapatkan di tutorial. ${ }^{8}$ Dalam kehidupan sehari-hari, elaborasi ilmu pengetahuan dapat terwujud dengan aktivitas tanya-jawab antar mahasiswa satu sama lain, dan juga dengan aktivitas pembuatan catatan. ${ }^{1}$ Berdasarkan hal di atas, hasil pembelajaran konstruktif yang sedang dapat menunjukkan bahwa aktivitas pertukaran informasi antar mahasiswa baik di tutorial, kuliah, praktikum, dan kehidupan sehari-hari, belum terjadi secara maksimal.

Tidak maksimalnya proses pertukaran informasi pada mahasiswa di atas dapat mempengaruhi proses aktivasi prior knowledge mahasiswa. Alasannya sesuai dengan Dolman et $\mathrm{al}^{1}$ yang menyebutkan bahwa aktivitas pertukaran informasi akan mendukung terjadinya aktivasi dari prior knowledge mahasiswa. Dengan saling bertukar informasi, maka mahasiswa akan semakin sering mengaktifkan prior knowledge yang dimilikinya. Sehingga melalui hal itu, pembelajaran konstruktif diharapkan akan terjadi secara maksimal.

Berdasarkan hasil rata-rata penilaian tingkat pelaksanaan pembelajaran mandiri di FKUGM (Tabel 6), didapatkan pelaksanaan pembelajaran mandiri di FK UGM adalah sedang: kontrol proses belajar telah berada pada diri mahasiswa sendiri, namun belum maksimal $(1,68)$. Tingkat pelaksanaan pembelajaran mandiri ditentukan oleh tiga hal, yaitu (a) planning , (b) monitoring, dan (c) evaluating proses pembelajaran. ${ }^{1,2,3,4,5}$

Hasil pelaksanaan pembelajaran mandiri yang sedang dalam penelitian ini mungkin menunjukkan bahwa mahasiswa belum secara maksimal dalam membuat perencanaan proses belajarnya. Melalui aktivitas planning, mahasiswa semestinya dapat mengetahui segala peluang dan hambatan yang akan dihadapinya. Dengan mengetahui peluang dan hambatan tersebut, maka mahasiswa akan dapat membuat strategi belajar yang tepat. Strategi belajar tersebut akan digunakan oleh mahasiswa untuk mencapai tujuan pembelajarannya. ${ }^{1,2,3,4}$

Terdapat dua hal yang dibutuhkan saat planning, yaitu (a) prior knowledge dalam diri mahasiswa. Dolman et $\mathrm{al}^{1}$ menyebutkan bahwa prior knowledge diperlukan untuk mengetahui kebutuhan belajar mahasiswa saat planning. Berdasarkan hal itu, hasil pelaksanaan pembelajaran mandiri yang sedang dapat menunjukkan bahwa kemungkinan mahasiswa belum secara maksimal menggunakan prior knowledge yang dimilikinya. Selain itu diperlukan juga (b) sumber belajar yang lengkap. Davis \& Harden ${ }^{3}$ dan Harsono ${ }^{4}$ menyebutkan bahwa sumber-sumber pembelajaran seperti pengajar dan literatur harus tersedia secara lengkap agar mahasiswa dapat mengerti sumber belajarnya saat merencanakan proses pembelajaran. Sehingga, hasil pelaksanaan pembelajaran mandiri yang sedang ini juga mungkin dapat disebabkan karena sumber belajar yang ada belum sepenuhnya tersedia secara lengkap.

Aktivitas planning dibutuhkan dalam seluruh aktivitas pembelajaran mahasiswa. Dalam diskusi tutorial, aktivitas planning tercermin dari tutorial pertama. Pada tutorial pertama, mahasiswa diharapkan dapat membuat suatu perencanaan materi belajar yang diwujudkan dalam 
bentuk learning objective. Learning objective tersebut akan disepakati oleh seluruh anggota kelompok dan setelah itu setiap anggota belajar atas dasar learning objective tersebut. ${ }^{8}$ Dalam kegiatan kuliah, aktivitas planning dapat tercermin dari persiapan mahasiswa sebelum kegiatan kuliah. Persiapan ini dapat dilakukan dengan membaca materi kuliah tahun lalu atau pun dengan membaca materi yang terkait dengan judul kuliahnya. ${ }^{8}$

Pada kegiatan praktikum, aktivitas planning juga diwujudkan dengan persiapan mahasiswa sebelum mengikuti praktikum. Persiapan ini dapat dilakukan dengan membaca dan memahami terlebih dahulu materi praktikum sebelum dilakukannya praktikum. Setelah itu, mahasiswa tersebut seharusnya dapat membuat suatu perencanaan dari langkah-langkah kerja (workplan) yang akan dilakukan saat praktikum. Dengan memahami serta dapat membuat rencana kerja praktikum, diharapkan mahasiswa telah dikatakan siap untuk menjalani praktikum tersebut. Untuk kegiatan sehari-hari, aktivitas planning dapat diwujudkan dengan masing-masing mahasiswa diharapkan memiliki perencanaan pribadi untuk proses belajarnya. Perencanaan pribadi tersebut dapat diwujudkan dengan memiliki learning objective pribadi, yaitu tujuan belajar selain dari yang dibahas di tutorial. $^{8}$

Hasil pelaksanaan pembelajaran mandiri yang sedang dalam penelitian ini mungkin juga menunjukkan bahwa proses monitoring pembelajaran belum sepenuhnya berjalan dengan lancar. Melalui monitoring proses pembelajaran, mahasiswa semesetinya dapat mengetahui pengetahuan yang telah dan yang belum dipelajarinya. Hal ini akan berguna dalam persiapan untuk mengantisipasi hambatan yang akan muncul kemudian. 1,2,5 Romauli et $\mathrm{al}^{8}$ memberikan contoh perwujudan dari proses monitoring dalam tutorial, yaitu ketika mahasiswa melakukan self learning di antara tutorial pertemuan pertama dan kedua. Pada self learning, mahasiswa diharapkan mencari sendiri jawaban dari learning objective yang ditetapkan di tutorial pertama. Hal ini dapat dilakukan dengan membaca berbagai macam referensi. Melalui hal itu, mahasiswa akan dapat melakukan monitoring proses belajarnya. Dalam kegiatan kuliah, aktivitas monitoring dapat tercermin melalui mahasiswa menghubungkan materi yang sedang dijelaskan dengan materi yang telah dipelajarinya. Melalui hal itu, maka mahasiswa akan dapat mengetahui hal-hal yang masih perlu dipelajari lebih lanjut. ${ }^{8}$

Aktivitas monitoring dalam praktikum tidak jauh berbeda dengan kuliah, yaitu mahasiswa dapat menghubungkan materi praktikum yang telah dimengerti dan materi praktikum yang belum dimengerti. ${ }^{8}$ Hal ini akan membuat mahasiswa mengetahui hal-hal yang perlu dipelajari lagi setelahnya. Sedangkan untuk kehidupan sehari-hari, aktivitas monitoring dapat diwujudkan dalam bentuk mahasiswa mengidentifikasi kesalahannya dalam proses belajar dan juga mahasiswa dapat mengulang materi yang telah dipelajari. ${ }^{8} \mathrm{Hal}$ ini penting dilakukan supaya mahasiswa dapat mengetahui hambatanhambatan dalam proses pembelajaran yang akan datang kemudian.

Selain menunjukkan kedua hal di atas, hasil pelaksanaan pembelajaran mandiri yang sedang dapat menunjukkan bahwa proses refleksi hasil belajar mahasiswa belum sepenuhnya terlaksana dengan baik. Harsono ${ }^{4}$ dan Kaufman ${ }^{5}$ menyebutkan bahwa dalam pembelajaran mandiri, mahasiswa seharusnya dapat merefleksikan hasil belajarnya disesuaikan dengan tujuan belajarnya saat planning.

Romauli et $\mathrm{al}^{8}$ menjelaskan perwujudan dari proses refleksi hasil belajar tersebut yaitu dengan membandingkan hasil belajar dengan teman. Hal ini dapat diwujudkan saat tutorial pertemuan kedua, kuliah, praktikum, ataupun dalam kehidupan sehari-hari. Selain itu, proses evaluasi pembelajaran semestinya dapat membuat mahasiswa lebih mengetahui lagi materi-materi yang masih harus dipelajarinya lagi. Contohnya adalah saat tutorial pertemuan kedua, mahasiswa diharapkan mengetahui materi-materi yang harus dipelajari setelahnya. Hal ini akan memicu mahasiswa untuk membuat learning objective pribadi setelah tutorial. ${ }^{8}$

Selain itu, aktvitas evaluating dalam praktikum dan kehidupan sehari-hari dapat diwujudkan dengan melakukan konsultasi pakar. ${ }^{8}$ Pada konsultasi pakar, mahasiswa diharapkan dapat menanyakan mengenai interpretasi hasil praktikum yang dibuat oleh mahasiswa kepada pembimbing praktikum bahwa sudah benar atau belum. Sedangkan dalam kehidupan sehari-hari, 
konsultasi pakar dapat dilakukan untuk menanyakan materi pembelajaran yang dirasa belum mendapatkan jawaban saat diskusi tutorial.

Pada saat proses evaluating proses pembelajaran, motivasi internal mahasiswa sangat dibutuhkan. Hal ini penting agar mahasiswa dapat terus melanjutkan proses belajar setelah proses evaluasi tersebut. Amin \& $\mathrm{Khoo}^{12}$ dan Dolman ${ }^{1}$ menjelaskan bahwa motivasi dari dalam diri sangat diperlukan saat melakukan evaluasi. Selain itu, Mustikarachmi et $\mathrm{al}^{16}$ juga menambahkan bahwa faktor motivasi dari dalam diri menjadi faktor utama kedua setelah faktor teman yang mempengaruhi mahasiswa untuk belajar secara mandiri.

Berdasarkan hasil rata-rata penilaian tingkat pelaksanaan pembelajaran kolaboratif di FK UGM (Tabel 6), didapatkan pelaksanaan pembelajaran kolaboratif di FK UGM adalah sedang: interaksi antar mahasiswa telah terjalin, namun belum maksimal $(1,85)$. Tingkat pelaksanaan pembelajaran kolaboratif ditentukan oleh tiga hal, yaitu (a) kesamaan tujuan belajar ${ }^{1}$, (b) adanya pembagian tugas dan tanggung jawab dalam diskusi tutorial $^{1,7,17}$, dan (c) ketergantungan yang mutual antar mahasiswa $^{1,7}$.

Hasil pelaksanaan pembelajaran kolaboratif yang sedang dalam penelitian ini mungkin menunjukkan bahwa tujuan belajar yang dimiliki antar mahasiswa belum sepenuhnya sama. Dolman et al ${ }^{1}$ menyebutkan bahwa tujuan belajar merupakan dasar dari aktivitas pembelajaran. Dengan adanya kesamaan dalam tujuan belajar, maka akan memudahkan untuk terjadinya interaksi antar mahasiswa.

Kesamaan tujuan belajar dapat diwujudkan dalam berbagai aktivitas pembelajaran. Dalam diskusi tutorial, kesamaan tujuan belajar dapat tercermin dari penetapan learning objective pada akhir tutorial pertemuan pertama. ${ }^{8}$ Dengan menetapkan learning objective secara bersamasama, dapat dikatakan bahwa mahasiswa telah memiliki kesamaan tujuan belajar. Melalui hal ini, interaksi antar mahasiswa yang memicu pembelajaran kolaboratif akan dapat terwujud. Dalam kegiatan kuliah, kesamaan tujuan pembelajaran dapat tercermin melalui penjelasan dosen pengajar mengenai tujuan pembelajaran dalam kuliahnya yang harus dikuasai oleh mahasiswa. Melalui penjelasan tersebut, semestinya akan tercipta kesamaan tujuan belajar antar mahasiswa.
Pada kegiatan praktikum, kesamaan tujuan belajar dapat diwujudkan melalui penjelasan mengenai tujuan dari praktikum yang akan dilakukan. Dalam buku panduan praktikum yang diterima mahasiswa, telah tertulis tujuantujuan yang harus dicapai oleh mahasiswa dalam praktikum tersebut. Dengan memahami tujuan praktikum tersebut, semestinya akan tercipta kesamaan tujuan pembelajaran antar mahasiswa. Pada kehidupan sehari-hari, kesamaan tujuan belajar dapat diwujudkan dengan membuat kelompok belajar diluar kegiatan akademik. ${ }^{8}$ Dengan adanya kelompok belajar tersebut, maka diharapkan kesamaan tujuan belajar akan terwujud sehingga interaksi antar mahasiswa akan dapat berjalan dengan maksimal. ${ }^{1,4}$

Hasil pelaksanaan pembelajaran kolaboratif yang sedang dalam penelitian ini mungkin juga menunjukkan bahwa pembagian tugas dan tanggung jawab antar mahasiswa dalam aktivitas pembelajaran belum sepenuhnya merata. Dillenbourg et $\mathrm{al}^{7}$ dan Dolman et $\mathrm{al}^{1}$ menyebutkan bahwa pembagian tugas dan tanggung jawab diperlukan dalam proses pembelajaran karena proses belajar tidak hanya dilakukan oleh salah seorang anggota kelompok, namun seluruh mahasiswa harus berperan secara aktif.

Pembagian tugas dan tanggung jawab paling terlihat dalam diskusi tutorial. Dalam diskusi tutorial, terdapat pembagian tugas dengan dipilihnya seorang ketua yang bertugas memimpin jalannya diskusi tutorial dan dua orang penulis yang bertugas mencatat jalannya proses diskusi tutorial. Sisanya berperan sebagai anggota dalam diskusi tutorial. ${ }^{4}$ Harsono ${ }^{4}$ menyebutkan bahwa dengan adanya pembagian tugas ini, bukan berarti bahwa mahasiswa yang menjadi ketua atau penulis boleh untuk tidak aktif saat diskusi. Harsono ${ }^{4}$ menyatakan bahwa seluruh anggota harus tetap berkontribusi secara aktif dalam diskusi. Kontribusi aktif tersebut dapat ditunjukkan dengan saling memberikan tanggapan atau kritikan kepada pendapat teman dalam diskusi. ${ }^{1}$ Dillenbourg et $\mathrm{al}^{7}$ menambahkan bahwa dengan adanya pembagian tugas dan tanggung jawab dalam diskusi tutorial ini, maka semestinya akan tercipta suatu interaksi yang terkoordinasi dan sinkron dalam proses pembelajaran. Dalam hal ini, tutor bertugas untuk memastikan semua anggota kelompok telah berpartisipasi secara aktif dalam diskusi tutorial tersebut. ${ }^{1}$ 
Dalam kegiatan kuliah, proses pembagian tugas dan tanggung jawab dapat terlihat dari saling bertukarnya catatan kuliah antar mahasiswa. ${ }^{8}$ Diharapkan dari proses tersebut, antar mahasiswa akan saling melengkapi catatan satu sama lain. Dalam praktikum, Romauli et $\mathrm{al}^{8}$ menyebutkan pembagian tugas dan tanggung jawab dapat terwujud dengan mahasiswa bekerja sama saat melakukan prosedur praktikum. Lalu dalam kehidupan sehari-hari, pembagian tugas dan tanggung jawab ini seharusnya dapat terjadi melalui aktivitas diskusi seharihari. Dalam diskusi akan terjadi pertukaran informasi antar mahasiswa sehingga masing-masing mahasiswa akan dapat melengkapi pengetahuannya masing-masing.

Selain menunjukkan dua hal di atas, hasil pelaksanaan pembelajaran kolaboratif yang sedang dalam penelitian ini dapat menunjukkan bahwa rasa saling ketergantungan antar mahasiswa belum tercipta secara maksimal. Ketergantungan yang mutual sangat penting dalam proses pembelajaran. Hal ini disebabkan karena dalam proses belajar, mahasiswa tidak bisa belajar secara sendiri. Mahasiswa membutuhkan dukungan satu sama lain. ${ }^{1,7}$

Ketergantungan antar mahasiswa dapat diwujudkan dalam berbagai aktivitas pembelajaran. Dalam aktivitas diskusi, baik di tutorial ataupun kehidupan sehari-hari, rasa ketergantungan antar mahasiswa semestinya dapat terwujud dengan saling berbagi informasi dan pengetahuan antar mahasiswa. ${ }^{1,7}$ Selain itu, Romauli et $\mathrm{al}^{8}$ menambahkan bahwa rasa ketergantungan yang bersifat mutual antar mahasiswa dapat tercermin melalui rasa saling menghargai pendapat teman saat berdiskusi. Dalam kegiatan kuliah, rasa ketergantungan mahasiswa dapat diwujudkan dengan saling bertukarnya catatan atau informasi mengenai materi kuliah antar mahasiswa. Sedangkan dalam praktikum, ketergantungan tersebut dapat terwujud dengan mahasiswa bekerja sama dalam mengerjakan prosedur praktikum. ${ }^{8}$ Melalui rasa ketergantungan yang mutual antar mahasiswa tersebut, diharapkan akan terbentuk suatu interaksi yang maksimal di antara mahasiswa.

Berdasarkan hasil rata-rata penilaian tingkat pelaksanaan pembelajaran kontekstual di FK UGM (Tabel 6), didapatkan pelaksanaan pembelajaran kontekstual di FK UGM adalah sedang: proses pembelajaran telah mencerminkan situasi dan kondisi lingkungan, tempat pengetahuan tersebut akan digunakan, namun belum maksimal $(1,61)$. Tingkat pelaksanaan pembelajaran kontekstual ditentukan oleh dua hal, yaitu (a) proses pembelajaran dengan konteks yang relevan ${ }^{1,2,3,18}$ dan (b) kemampuan mahasiswa untuk melihat masalah yang dihadapi dari berbagai sudut pandang ${ }^{1,18}$.

Hasil pelaksanaan pembelajaran kontekstual yang sedang dalam penelitian ini mungkin menunjukkan bahwa proses pembelajaran belum sepenuhnya memiliki konteks yang relevan dengan situasi dan kondisi nyata. Charlin et $\mathrm{al}^{2}$ dan Dolman et $\mathrm{al}^{1}$ menyebutkan bahwa pengetahuan lebih mudah didapatkan pada situasi dan kondisi yang tepat. Hal ini didukung oleh Davis \& Harden $^{3}$ yang menyatakan bahwa situasi dan kondisi yang tepat akan lebih menggambarkan hal-hal yang nantinya akan dihadapi oleh mahasiswa dalam kehidupan nyata.

Proses pembelajaran dengan konteks yang relevan dapat diterapkan di berbagai aktivitas pembelajaran. Dalam tutorial, masalah yang diberikan kepada mahasiswa semestinya diambil dari kasus yang relevan terjadi pada pasien. ${ }^{1} \mathrm{Hal}$ ini akan lebih memberikan gambaran kepada mahasiswa mengenai hal-hal yang akan dihadapi nantinya sesuai dengan situasi dan kondisi yang terjadi. ${ }^{3}$ Dalam tutorial ini, tutor bertugas untuk membantu memberikan gambaran mengenai pengalamannya selama ini yang sesuai dengan masalah yang dihadapi mahasiswa. ${ }^{1}$

Dalam kegiatan kuliah, proses pembelajaran dengan konteks yang relevan dapat terwujud melalui materi kuliah yang disampaikan dosen pengajar semestinya dapat memberikan gambaran mengenai situasi dan kondisi dari kasus yang dijelaskan. Dengan pemberian gambaran mengenai situasi dan kondisi yang sering dihadapi, diharapkan mahasiswa akan dapat menggunakan materi yang diberikan dalam situasi dan kondisi nyata. Dalam praktikum, materi praktikum yang dilakukan mahasiswa juga semestinya merupakan materimateri yang nantinya akan sering dihadapi dalam kondisi nyata sebagai dokter. Melalui hal itu, diharapkan mahasiswa akan dapat mengaplikasikan materi praktikum tersebut saat nanti menjadi dokter. Dalam kehidupan sehari-hari, Romauli et $\mathrm{al}^{8}$ memberikan contoh perwujudan proses pembelajaran dengan konteks 
yang relevan yaitu dengan mempelajari penerapan klinis dari ilmu pengetahuan yang dipelajari mahasiswa. Salah satu caranya adalah dengan mengunjungi pusat pelayanan kesehatan. ${ }^{8} \mathrm{Hal}$ ini akan membuat mahasiswa dapat mengerti kegunaan dari pengetahuan yang dipelajarinya, sehingga ilmu yang dipelajarinya tersebut dapat dapat digunakan dalam kehidupan sehari-hari.

Hasil pelaksanaan pembelajaran kontekstual yang sedang dalam penelitian ini juga mungkin menunjukkan bahwa mahasiswa belum sepenuhnya melihat permasalahan yang dihadapi dari berbagai sudut pandang. Dammers et $\mathrm{al}^{18}$ dan Dolman et $\mathrm{al}^{1}$ menyebutkan bahwa situasi yang nantinya akan dihadapi mahasiswa ketika menjadi dokter akan berbeda-beda. Hal ini menyebabkan mahasiswa harus mampu menggunakan ilmu pengetahuan yang dimilikinya sesuai dengan situasi dan kondisi yang sedang dihadapi.

Penerapan dari melihat masalah dari berbagai sudut pandang dapat dilakukan di berbagai aktivitas pembelajaran. Dalam diskusi tutorial, mahasiswa seharusnya dapat melihat skenario kasus yang diberikan dari berbagai macam sudut pandang. ${ }^{1} \mathrm{Hal}$ ini diperlukan supaya mahasiswa siap dalam menghadapi segala situasi dan kondisi yang terjadi terkait dengan kasus yang dihadapi. Dalam kegiatan kuliah, dosen pengajar juga semestinya dapat memberikan gambaran seputar materi yang diberikan dari berbagai macam sudut pandang. ${ }^{8}$ Melalui hal itu, mahasiswa akan menjadi lebih mudah dalam mengidentifikasi berbagai situasi dan kondisi yang akan terjadi berkaitan dengan materi kuliah dosen.

Dalam praktikum, dosen pembimbing praktikum juga semestinya dapat memberikan berbagai gambaran mengenai kegunaan materi praktikum yang dilakukan mahasiswa dari berbagai sudut pandang. ${ }^{8}$ Sedangkan dalam kehidupan sehari-hari, melihat permasalahan yang dihadapi dari berbagai sudut pandang dapat diterapkan melalui mahasiswa mencoba membandingkan ilmu yang dipelajari dengan permasalahan dalam kehidupan sehari-hari. Selain itu, mahasiswa juga dapat memikirkan kemungkinankemungkinan yang dapat terjadi terkait dengan permasalahan tersebut. ${ }^{8} \mathrm{Hal}$ ini semestinya akan menimbulkan pola pikir kritis pada mahasiswa. Pola pikir kritis inilah yang akan menstimulus terjadinya proses pembelajaran. ${ }^{1}$
Tingkat pelaksanaan PBL di FK UGM berdasarkan pembelajaran konstruktif, mandiri, kolaboratif, dan kontekstual pada angkatan 2007 dan 2008 (Tabel 7) adalah sama, yaitu sedang. Analisis statistik dengan menggunakan uji Independent Sample T-Test menunjukkan tidak adanya perbedaan yang bermakna tingkat pelaksanaan pembelajaran konstruktif $(\mathrm{p}=0,921)$, mandiri $(\mathrm{p}=0,994)$, kolaboratif $(\mathrm{p}=0,864)$, kontekstual $(\mathrm{p}=0,701)$, dan PBL $(p=0,945)$ pada kedua kelompok mahasiswa tersebut.

Tidak adanya perbedaan yang bermakna tersebut kemungkinan dapat disebabkan karena sistem pendidikan yang dijalani oleh kedua angkatan ini di FK UGM adalah sama. Keseluruhan aktivitas pembelajaran yang dijalani oleh angkatan 2007, dijalani juga oleh angkatan 2008 satu tahun berikutnya. Selain itu, keduanya juga memiliki kurikulum yang sama yaitu Kurikulum Berbasis Kompetensi. ${ }^{19}$

Hasil tersebut berbeda dengan Gursel et $\mathrm{al}^{20}$ yang menyebutkan bahwa mahasiswa tingkat awal memiliki lebih banyak waktu untuk belajar. Namun, walaupun memiliki waktu lebih banyak untuk belajar, ternyata hal tersebut tidak mempengaruhi tingkat pembelajaran mandirinya. Miflin et $\mathrm{al}^{21}$ dan Kocaman et $\mathrm{al}^{22}$ menyebutkan bahwa kemandirian belajar dalam mahasiswa merupakan suatu proses maturasi, sehingga mahasiswa tingkat awal akan cenderung memiliki tingkat kemandirian belajar yang lebih rendah dibandingkan mahasiswa lama. Hal tersebut dapat menunjukkan bahwa aktivitas planning, monitoring, dan evaluating proses pembelajaran mahasiswa tingkat awal masih lebih rendah dibandingkan mahasiswa lama.

Selain itu, Gursel et a ${ }^{20}$ menyebutkan bahwa mahasiswa lama menggunakan lebih banyak referensi saat diskusi tutorial dibandingkan mahasiswa tingkat awal. Hal ini semestinya akan mendukung proses pembelajaran konstruktif pada mahasiswa lama. ${ }^{8}$ Selain itu, dengan banyaknya referensi yang digunakan, maka proses pertukaran informasi antar mahasiswa akan lebih banyak terjadi. Tentunya hal ini akan mendukung proses pembelajaran kolaboratif. ${ }^{1}$

Azer \& Eizenberg ${ }^{23}$ juga menambahkan bahwa mahasiswa lama sudah lebih mengerti penggunaan klinis dari materi yang dipelajari. Hal ini dapat menunjukkan bahwa mahasiswa lama semestinya memiliki tingkat pembelajaran kontekstual yang lebih tinggi dibandingkan mahasiswa tingkat awal. 
Tingkat pelaksanaan PBL di FK UGM berdasarkan pembelajaran konstruktif, mandiri, kolaboratif, dan kontekstual pada program reguler dan internasional (Tabel 8) adalah sama, yaitu sedang. Analisis statistik dengan menggunakan uji Independent Sample T-Test menunjukkan adanya perbedaan yang bermakna pelaksanaan $\mathrm{PBL}$ antara program reguler dan internasional dalam pembelajaran konstruktif $(\mathrm{p}=0,001)$ dan kontekstual $(p=0,000)$, sedangkan untuk pembelajaran mandiri $(\mathrm{p}=0,119)$ dan kolaboratif $(p=0,576)$ diperoleh tidak adanya perbedaan yang bermakna.

Tidak adanya perbedaan yang bermakna pada pelaksanaan pembelajaran mandiri ini mungkin dapat disebabkan karena kemandirian belajar pada mahasiswa tidak dipengaruhi oleh perbedaan budaya dan karakteristik personal seperti yang ada pada kedua kelompok mahasiswa ini. ${ }^{24}$ Harden ${ }^{24}$ cit Tavakol \& Denik menyebutkan bahwa kemandirian belajar pada mahasiswa datang dari dalam diri mahasiswa sendiri. Kemandirian belajar tersebut yang akan memicu rasa butuh mahasiswa akan ilmu pengetahuan sehingga akan memicunya untuk terus belajar.

Tidak adanya perbedaan yang bermakna pada pelaksanaan pembelajaran kolaboratif ini mungkin dapat disebabkan karena kedua kelompok mahasiswa tersebut sama-sama telah mengikuti program orientasi mahasiswa saat menjadi mahasiswa baru. ${ }^{25}$ FK UGM setiap awal tahun pembelajaran, selalu mengadakan program orientasi terhadap seluruh mahasiswa baru, baik reguler maupun internasional. Program ini bertujuan untuk mengenalkan berbagai kondisi lingkungan yang ada di FK UGM. Sheehan \& Pearson (cit Talbot et al) ${ }^{25}$ menyebutkan bahwa melalui program orientasi tersebut, faktor-faktor yang akan menghambat mahasiswa, khususnya mahasiswa internasional untuk berinteraksi, seperti perbedaan dalam hal bahasa, karakteristik individu, dan budaya, akan dapat teratasi.

Adanya perbedaan yang bermakna pada pelaksanaan pembelajaran konstruktif mungkin dapat disebabkan karena perbedaan cara belajar yang digunakan antara mahasiswa reguler dan internasional. ${ }^{27}$ Shankar et al ${ }^{26}$ menyebutkan bahwa cara belajar tersebut, dapat dipengaruhi oleh keterbiasaannya pada bahasa yang digunakan dalam materi pembelajaran.
Dalam sistem pembelajaran di FK UGM, hampir seluruh materi pembelajaran mahasiswa (buku panduan blok, buku panduan praktikum, kasus tutorial, slide kuliah dosen, dan textbook), baik untuk internasional maupun reguler, ditulis dengan menggunakan bahasa Inggris. ${ }^{13}$ Pada program internasional di FK UGM, mayoritas mahasiswanya berasal dari Malaysia, yang dalam aktivitas sehari-harinya telah terbiasa menggunakan bahasa Inggris. Hal ini menyebabkan, mahasiswa internasional lebih terbiasa untuk mencerna informasi dalam bahasa Inggris.

Shankar et $\mathrm{a}^{26}$ menyebutkan bahwa mahasiswa yang terbiasa dengan bahasa yang digunakan pada materi pembelajaran, akan cenderung memiliki cara belajar deep learning. Cara belajar deep learning menjelaskan bahwa mahasiswa mempelajari suatu materi secara mendalam dan bertujuan untuk memperoleh suatu pemahaman akan materi tersebut. Melalui proses pembelajaran yang mendalam tersebut, semestinya diperoleh pondasi bangunan ilmu pengetahuan yang lebih kuat, yang mendukung proses pembelajaran konstruktifnya.

Adanya perbedaan yang bermakna pada pelaksanaan pembelajaran kontekstual mungkin dapat disebabkan karena adanya perbedaan pada pelaksanaan beberapa aktivitas pembelajaran antara program reguler dan internasional, seperti pada diskusi tutorial, kuliah, dan praktikum. ${ }^{13}$

Di FK UGM, terdapat perbedaan pada pelaksanaan ketiga aktivitas pembelajaran tersebut antara program reguler dan internasional, di antaranya adalah perbedaan dalam hal tutor yang memfasilitasi jalannya tutorial, dosen yang memberikan kuliah, dan pembimbing dalam praktikum (untuk laboratorium Anatomi dan Biokimia, program reguler tidak ditangani oleh dosen, namun oleh asisten dosen). ${ }^{13}$ Dalam pembelajaran yang kontekstual, baik tutor, dosen pengajar, maupun pembimbing praktikum bertugas untuk membantu memberikan gambaran mengenai situasi dan kondisi yang sering dihadapi berkaitan dengan materi, beserta kegunaannya dalam kehidupan nyata. ${ }^{1,8}$ Perbedaan pada ketiga hal tersebut, dapat menyebabkan adanya perbedaan mengenai gambaran yang diterima oleh mahasiswa. $\mathrm{Hal}$ ini dapat menyebabkan adanya perbedaan pandangan pada mahasiswa mengenai konteks materi yang dipelajarinya, sehingga pembelajaran kontekstualnya juga dapat berbeda. 


\section{KESIMPULAN}

Berdasarkan hasil penelitian ini, diperoleh beberapa kesimpulan yaitu:

1. Instrumen/kuesioner yang dikembangkan dari hasil penelitian Romauli et $\mathrm{al}^{8}$ memiliki tingkat validitas dan reliabilitas yang tinggi untuk mengukur pelaksanaan PBL berdasarkan pembelajaran konstruktif, mandiri, kolaboratif, dan kontekstual.

2. Tingkat pelaksanaan PBL di FK UGM telah menstimulus mahasiswa untuk membangun ilmu pengetahuannya, namun perlu untuk ditingkatkan lagi.

3. Tingkat pelaksanaan PBL di FK UGM telah menstimulus kontrol proses belajar berada pada diri mahasiswa sendiri, namun perlu untuk ditingkatkan lagi.

4. Tingkat pelaksanaan PBL di FK UGM telah menstimulus terjadinya interaksi antar mahasiswa, namun perlu untuk ditingkatkan lagi.

5. Tingkat pelaksanaan PBL di FK UGM telah menstimulus terjadinya proses pembelajaran yang mencerminkan situasi dan kondisi lingkungan, tempat pengetahuan tersebut akan digunakan, namun perlu untuk ditingkatkan lagi.

6. Tidak terdapat perbedaan yang bermakna pelaksanaan PBL berdasarkan pembelajaran konstruktif, mandiri, kolaboratif, dan kontekstual antara angkatan 2007 dan 2008.

7. Terdapat perbedaan yang bermakna pelaksanaan PBL antara program regular dan internasional dalam pembelajaran konstruktif dan kontekstual, namun tidak ada perbedaan yang bermakna untuk pembelajaran mandiri dan kolaboratif.

\section{SARAN}

1. Diharapkan dapat dilakukan penelitian sejenis dengan subjek penelitian yang lebih besar dan dapat berasal dari universitas yang berbeda sehingga didapatkan data perbandingan dari hasil penelitian ini.

2. Hasil yang diperoleh pada penelitian ini dapat digunakan sebagai bahan evaluasi program pelaksanaan PBL di FK UGM selama ini, untuk kemudian diperbaiki dan ditingkatkan kualitasnya, antara lain: (a) untuk meningkatkan kemampuan mahasiswa dalam membangun ilmu pengetahuannya, diharapkan kualitas masalah dapat ditingkatkan dan kemampuan tutor untuk memancing prior knowledge mahasiswa juga dapat ditingkatkan,

(b) untuk meningkatkan kontrol proses belajar pada diri mahasiswa, diharapkan fakultas dapat meningkatkan lagi sumber-sumber pembelajaran seperti literature, textbook, dan jurnal, serta kemampuan tutor dalam membantu memonitor dan mengevaluasi proses belajar mahasiswa juga dapat ditingkatkan,

(c) untuk meningkatkan terjadinya interaksi antar mahasiswa, diharapkan pihak fakultas dapat meningkatkan proses penyampaian tujuan belajar yang harus dicapai oleh mahasiswa dan kemampuan tutor untuk memastikan seluruh mahasiswa telah berkontribusi juga dapat ditingkatkan,

(d) untuk meningkatkan terjadinya proses pembelajaran yang mencerminkan situasi dan kondisi lingkungan, tempat pengetahuan tersebut akan digunakan, diharapkan pihak fakultas dapat meningkatkan aktivitas pemaparan klinis secara dini terhadap mahasiswa dan juga kemampuan tutor dalam memberikan gambaran mengenai situasi dan kondisi yang sering dihadapinya dapat ditingkatkan.

3. Selain itu dapat juga dilakukan penelitian lain mengenai faktor-faktor yang menyebabkan adanya perbedaan pelaksanaan PBL berdasarkan pembelajaran konstruktif, mandiri, kolaboratif, dan kontekstual antara program reguler dan internasional di FK UGM ataupun Fakultas Kedokteran di universitas lain yang membuka program internasional.

\section{DAFTAR PUSTAKA}

1. Dolman D, Willem de Grave, Wolfhagen I, Van der Vleuten. Problem-based learning: future challenges for educational practice and research. Medical Education. 2005;39:732-41. 
2. Charlin B, Mann K, Hansen P. The many faces of problem-based learning: a framework for understanding and comparison. Medical Teacher. 1998;20:323 30 .

3. Davis MH, Harden RM. AMEE Medical Education Guide No. 15: problem-based learning: a practical guide. Medical Teacher. 1999;21130-40.

4. Harsono. Pengantar problem-based learning Edisi Kedua. Yogyakarta: Medika Fakultas Kedokteran UGM; 2003.

5. Kaufman A. The New Mexico experiment: educational innovation and institutional change. Acad Medicine.1989;64:185-204.

6. Pouyioutas P, Solomou E, Ioannou C. Problem based learning in the educational system of Cyprus. [internet]. 2009 [cited 2009 July 17]. Available from http://www.unic.ac.cy/media/Research/Photos/ papereuclides.pdf.

7. Dillenbourg P, Baker M, Blaye A \& O’Malley C. The evolution of research on collaborative learning. Learning in humans and machine: towards an interdisciplinary learning science. 1996; 189-211.

8. Romauli T, Rahayu GR, Suhoyo Y, Dibyasakti BA, Mustikarachmi VS. Pengembangan indikatorindikator tingkat pelaksanaan PBL berdasarkan pembelajaran konstruktif, mandiri, kolaboratif, dan kontekstual. Jurnal Pendidikan Kedokteran dan Profesi Kesehatan Indonesia. 2009;4(1):46-57.

9. Sugiyono. Metode penelitian kuantitatif, kualitatif, dan R \& D. Bandung: Alfabeta; 2008.

10. Morgan GA, Leech NL, Gloeckner GW, Barrett KC. SPSS for introductory statistics: use and interpretation. Second Edition. New Jersey: Lawrence Erlbaum Associates Publisher; 2004.

11. Triola MM, Triola MF. Biostatistics for the biological and health science. Boston: Pearson Addison Weasley; 2006.

12. Amin Z, Kho HE. Basics in medical education. Singapore: World Scientific; 2003.

13. Panduan akademik fakultas kedokteran 2005/2006. Yogyakarta: FK UGM; 2005.

14. Savery JR, Duffy TM. Problem based learning: an instructional model and its constructivist framework. Educational Technology. 1995;35:31-8.

15. Caplow JAH, Donaldson JF, Kardash CA, Hosokawa M. Learning in a problem-based medical curriculum: students' conceptions. Medical Education. 1997;31:440-7.
16. Mustikarachmi VS, Rahayu GR, Suhoyo Y, Dibyasakti BA, Romauli T. Faktor-faktor yang mempengaruhi mahasiswa FK UGM untuk melakukan pembelajaran konstruktif, mandiri, kolaboratif, dan kontekstual dalam problem based learning. Jurnal Pendidikan Kedokteran dan Profesi Kesehatan Indonesia. 2009;4(1): 32-45.

17. Nieminen J, Sauri P, Lonka K. On the relationship between group functioning and study success in problem-based learning. Medical Education. 2006;40:64-71.

18. Dammers J, Spencer J, Thomas M. Using real patients in problem-based learning: students' comments on the value of using real, as opposed to paper cases in a problem-based learning module in general practice. Medical Education. 2001;35:27-34.

19. Panduan akademik fakultas kedokteran 2009/2010. Yogyakarta: FK UGM; 2009.

20. Gursel Y, Musal B, Taskiran HC, Ozan S, Tuna A. Perception of first and third year medical students on self-study and reporting process of problem-based learning. Medical Education. 2004, 4:16.

21. Mifflin BM, Campbell CB, Price DA. A conceptual framework to guide the development of self-directed, lifelong learning in PBL. Medical Education. 2000; 34: 299-306.

22. Kocaman G, Dicle A, Ugur A. A longitudinal analysis of the self-directed learning readiness level of nursing students enrolled in a problem-based curriculum. Journal of Nursing Education. 2009:48(5):286-90.

23. Azer SA, Eizenberg N. Do we need dissection in an integrated problem-based learning medical course? Perception of first- and second-year students. Surg Radiol Anat. 2007; 29:173-80.

24. Tavakol M, Denik R. Are Asian international medical students just rote learners? [internet] 2009 [cited on 2009 Dec 19] Available from: http://www. springerlink.com/ index/v1x3316677m 03560.pdf.

25. Talbot DM, Geelhoed RJ, Ninggal MT. A qualitative study of Asian international students' attitudes toward African Americans. NASPA Journal. 1999;36(3):21021.

26. Shankar PR, Dubey AK, Binu VS, Subish P, Deshpande VY. Learning styles of preclinical students in a medical college in western Nepal. Kathmandu University Medical Journal. 2006;4(3):390-5. 